\title{
INOVASI DISRUPTIF TRANSPORTASI DI JAKARTA
}

\author{
Erwin Rasyid ${ }^{\circledR 1)}$ dan Iman Chaerudin ${ }^{(2)}$ \\ ${ }^{1,2)}$ Program Studi Manajemen, STIE Unisadhuguna \\ ${ }^{1,2}$ Jalan Terogong Raya No.32, Kota Jakarta Selatan, Daerah Khusus Ibukota Jakarta 12430, Indonesia \\ E-mail : erwin.rasjid@ubs-usg.ac.id ${ }^{1)}$,iman.chaerudin@ubs-usg.ac.id ${ }^{2)}$
}

\begin{abstract}
ABSTRAK
Indonesia merupakan salah satu negara yang terkena dampak Krisis Keuangan Asia Tenggara antara tahun 1997 dan 1998. Dampak negatif tidak pernah hilang sama sekali. Selama periode itu, banyak bisnis, besar dan menengah terpaksa gulung tikar karena ketidakmampuan mereka dalam menghadapi waktu percobaan. Jutaan, buruh dan karyawan, terkena PHK besar-besaran. Pada masa tersebut, Indonesia mengalami lonjakan kegiatan ekonomi informal yang dilakukan oleh mereka yang memiliki keterampilan teknis dan nonteknis. PT Go-Jek Indonesia (Go-Jek) merupakan anomali yang berkembang menjadi fenomena ekonomi inovatif. Meski ada keraguan, Go-Jek mampu memberikan peluang, meski secara informal kepada 200.000 pengendara ojek, 100.000 beroperasi di Jakarta, angka tersebut tidak termasuk mereka yang bertugas di divisi operasi dan manajerial. Internet telah secara signifikan menurunkan penghalang masuk bagi banyak inovator yang mengganggu, termasuk Go-Jek. Perusahaan, yang mematuhi tiga prinsip utama: kecepatan, inovasi, dan dampak sosial, berdiri dibandingkan dengan pengganggu populer lainnya yang muncul dan bercabang di negara-negara di mana kapitalisme liberal berkembang. Go-Jek terus menerus menuai kontroversi, seperti halnya inovator pengganggu lainnya di seluruh dunia, karenanya, dialog dan bimbingan dari pemerintah, untuk mencegahnya menerapkan praktik monopoli serta mencegahnya menerima serangan balik di masa depan dari para pesaing lama. Serangan balik yang terjadi baru-baru ini dari salah satu pesaing lama telah menempatkan pelanggan dan masyarakat Jakarta dalam persaingan yang ketat. Populasi dalam penelitian ini adalah kelompok warga Jakarta dan mitra Go-Jek, kecuali di wilayah Kepulauan Seribu yang belum tersedia jaringan Go-Jek. Hasil penelitian menunjukkan bahwa persepsi masyarakat terhadap fenomena Go-Jek sangat positif. Hal ini terlihat dari respon konsumen yang menganggap Go-Jek merupakan alternatif transportasi yang sudah lama dicari, ketika angkutan umum semakin menjadi permasalahan yang pelik di Jakarta. Go-Jek telah membuka kesempatan kerja bagi mereka yang menginginkan keleluasaan dalam menentukan waktu kerja dan juga kebutuhan. Ketegasan pemerintah dalam membuat kerangka kerja agar pengguna (masyarakat) dan inovator tidak melanggar hukum dan mematuhi ketentuan yang ada.
\end{abstract}

Kata Kunci: Inovasi Disruptif, Transportasi Online, Kualitas Pelayanan, Go-Jek

\section{PENDAHULUAN}

Dewasa ini sering kita mendengar istilah disruptif, banyak sekali yang mengatakan disruptif adalah era gangguan. Era "Gangguan" yang dianggap bayak merugikan beberapa orang, komunitas, lembaga bahkan sebuah Negara. Banyak sekali kita mendengar dan membaca berita perusahan mengalami penurunan pendapatan dan bahkan tidak sedikit yang mengalami gulung tikar. Era disruptif tidak dapat dilepaskan seiring perkembangan teknologi yang begitu pesat, dimana teknologi ini memberikan warna, dan pembaruan yang cukup mengguncang peradaban di berbagai belahan dunia. Teknologi memunculkan berbagai inovasi, memunculkan kebaruan dan meninggalkan berbagai sistem konvensional. Taxi konvensional mulai ditinggalkan, ojek pangkalan mulai tersingkirkan, seiring munculnya sarana transportasi berbasis aplikasi seperti Go-Jek dan Grab. Koran ditinggalkan beralih pada berita online.

Menurut Dewi dan Darma (2019) inovasi yang mengganggu merupakan bentuk gangguan oleh pendatang baru, pendatang baru tersebut berkompetisi dengan perusahaan incumbent yang sudah mapan. Inovasi yang mengganggu tersebut digambarkan dengan sebuah kemampuan untuk memanfaatkan sesuatu yang baru dalam satu lini. Sedangkan Agung dan Darma (2019); Ferdiana, A.M.K., dan Darma, G.S. (2019) mengungkapkan bahwa lini yang dimanfaatkan dalam inovasi ini adalah lini terendah yakni para pelanggan yang cepat mendapatkan rasa kepuasan. Sedangkan lini tertinggi dalam hal ini digambarkan dengan pelanggan yang memiliki tuntutan yang tinggi. Distribusi pelanggan ini yang secara median dapat diambil sebagai garis putus-putus untuk menerapkan teknologi baru. Ditambahkan pula Darma (2018) dan Schor, J. (2016) bahwa inovasi dikatakan sebagai hal yang mengganggu jika inovasi tersebut membawa teknologi baru yang lebih murah dan memudahkan dibanding teknologi sebelumnya. Efisiensi yang ditawarkan karena harga yang murah akhirnya mengganggu teknologi lama yang mahal dan tidak efisien (Kostakis, V., \& Bauwens, M. 2014). Pemahaman kedua mengenai inovasi yang 
mengganggu ini apabila terjadi pada industri yang sama. Jika inovasi yang dilakukan tidak membuat pelaku industri lama terganggu atau di lain pihak secara tidak langsung mengganggu industri lain, maka inovasi tersebut tidak dapat dikatakan sebagai inovasi yang mengganggu.

Inovasi disruptif bukan saja datang mengganggu, menghancurkan dan menggantikan teknologi lama. Keberhasilan incumbent dalam melakukan persaingan menghadapi serangan para pelaku usaha bisnis baru tidak ada jaminan dapat bertahan untuk waktu yang panjang. Kasali (2017); Darma (2019) mengungkapkan bahwa ada enam perangkap, pertama success trap atau complacency trap, perangkap yang datang dari keberhasilan pada masa lalu. Success trap adalah satu dari enam perangkap yang terlihat sangat mengemuka pada era disruption sekarang ini. Lima perangkap lainnya adalah the competency trap, the sunk-cost trap, the blame trap, the cannibalization trap dan the confirmation trap. Pengusaha yang telah mapan seharusnya menyadari bahwa adanya globalisasi dan modernisasi Goodman, J. A. (2014). Keberadaan inovasi yang mengganggu di Indonesia adalah sebuah keniscayaan. Berbagai konflik muncul karena adanya inovasi yang mengganggu ini dan berujung pada kekerasan (Setyanti, 2015). Peran pemerintah sebagai regulator tentunya sangat diperlukan untuk menemukan solusi melalui konsolidasi. Hal tersebut terungkap dalam penelitian yang berjudul Inovasi Disruptif di Industri Perhotelan (Bayudin. 2019).

Inovasi Disruptif ini biasanya mengambil segmen pasar tertentu yang kurang diminati atau dianggap kurang penting bagi penguasa pasar, namun inovasinya bersifat breakthrough dan mampu me-redefinisi sistem atau pasar yang existing. Munculnya Inovasi Disruptif jika tidak diantisipasi dengan baik oleh dunia usaha dapat menyebabkan kejatuhan (Widia Darma, 2018).

Inovasi dan teknologi kini menjadi faktor-faktor baru pembuka lapangan kerja (Cosseboom, L. 2015). Teknologi informatika kini bukan hanya menjadi jalur komunikasi, namun menjadi media bagi jutaan orang untuk menghidupi diri dan keluarga mereka, kendati mereka tidak memiliki pendidikan tinggi. Indonesia merupakan salah satu negara di dunia dengan penetrasi smartphone terbesar. Menurut survei Google Indonesia yang bekerja sama dengan TNS Global Market Research tahun 2015, penetrasi smartphone melonjak tajam di Q1 2015 menjadi $43 \%$ dibandingkan di periode yang sama tahun sebelumnya, yaitu $28 \%$. Menurut survei tersebut, empat dari sepuluh orang Indonesia kini menggunakan smartphone.

Menurut Kementerian Komunikasi dan Informatika (Kemenkominfo, 2016) yang mengutip survei eMarketeer, mengatakan bahwa populasi smartphone Indonesia diproyeksikan mencapai 100 juta pada tahun 2018. Oleh sebab itu perusahaan-perusahaan penyedia jasa berbasis aplikasi smartphone berlomba-lomba untuk menguasai pasar. Namun, senada dengan yang terjadi di berbagai negara lain, resistensi terjadi, baik resistensi yang datang dari penyedia moda transportasi berbasis aplikasi smartphone, yang menjadi dark horse penggerogot pangsa pasar, juga dari komunitas para transportasi (misalnya: ojek pangkalan, bajaj, bemo, dll.) (Setyanti, 2015).

Peer-to-peer economy ( $P 2 P$ economy) yang sering juga disebut sharing economy merupakan fenomena kontemporer yang berakar dari paham disruptive innovation yang diperkenalkan oleh Clayton Christensen (2013). Popularitas sharing economy terpicu krisis ekonomi Amerika Serikat pada tahun 2008. Inflasi dan harga kebutuhan dasar yang meningkat, membuat banyak orang terpaksa "berbagi" aset-aset mereka yang jarang digunakan (underutilized) untuk menambah pemasukan (Schor, J., 2016).

Kemiskinan dan minimnya lapangan kerja di Indonesia, khususnya ibukota Jakarta telah menjadi isu dan problema yang berkepanjangan. Banyak diantara mereka yang kurang beruntung dalam berkompetisi di dunia bekerja memilih untuk bekerja secara informal bahkan serabutan guna menutupi kebutuhan keseharian mereka dan keluarga mereka. Salah satu pekerjaan informal yang banyak dilakukan di Indonesia adalah Ojek Motor. Ojek bukan fenomena unik Indonesia, lebih cenderung disebut fenomena Asia, dimana terdapat negara-negara berpenduduk terpadat di dunia. Ojek, apapun sebutan lokal mereka (motodops di Kamboja, habal-habal di Filipina, vin mosai di Thailand, dll.), dapat ditemukan seantero Asia Tenggara.

Freakonomics, sebuah buku yang dikarang Steven Levitt, ekonom di Universitas Chicago, dan Steven J. Dubner, seorang jurnalis ekonomi, menggunakan teori ekonomi ke sejumlah fenomena sosial yang biasanya tidak diteliti oleh para ekonom konvensional. Levitt dan Dubner menyatakan bahwa pada dasarnya, ekonomi merupakan penelusuran/studi tentang insentif, yakni bagaimana cara orang-orang mendapatkan apa yang mereka inginkan atau butuhkan, terutama ketika orang lain menginginkan atau membutuhkan hal yang sama ( $\mathrm{J}$. K. 2012).

PT. Go-Jek Indonesia (Go-Jek) merupakan salah satu contoh sukses bentuk usaha rintisan yang disruptif namun memiliki akar-akar social entrepreneurship inovatif yang menjawab tantangan yang sudah ada sejak lama dialami di DKI Jakarta, antara lain: kerisauan masyarakat akibat kemacetan yang parah, keterbatasan moda transportasi instan (dapat ditemui di mana saja) dan time sensitive (dapat ditemui kapan saja), serta tidak adanya standar tarif layanan ojek konvensional yang menyebabkan proses tawar menawar yang alot antara penumpang dan pengemudi ojek. Namun dalam perkembangannya, Gojek sering menemui resistensi baik dari elemen masyarakat (pengemudi ojek pangkalan, dll), maupun dari pihak legislator (Hanggoro, 2015).

Hal yang ingin penulis sampaikan dalam penelitian ini adalah bagaimana fenomena Inovasi disruptif di bidang transportasi. Yang penulis harapkan akan memberikan kepada industri transportasi, pelanggan dan 
juga pemerintah sebagai regulator yang akan menerbitkan kebijakan-kebijakan pada industri transportasi online. Juga kepada pengusaha diharapkan setelah membaca penelitian ini dapat mendapatkan masukan untuk mengembangkan usahanya.

\section{RUANG LINGKUP}

Lingkup penelitian ini dibatasi dalam lingkup wilayah DKI Jakarta, dan hanya membahas isu persepsi pelanggan dan mitra Go-Jek di wilayah DKI Jakarta, tidak termasuk Kepulauan Seribu. berikut:

Sedangkan tujuan penelitian ini adalah sebagai

1. Untuk mengetahui persepsi masyarakat sehubungan dengan appeal Go-Jek sebagai moda transportasi berbasis aplikasi bagi sebagian warga Jakarta dibandingkan dengan transportasi umum konvensional

2. Untuk mengetahui sejauh mana peran Go-Jek sebagai disruptor dengan prinsip Social Entrepreneurship merupakan pola bisnis padat karya dan membantu perekonomian mitra-mitra mereka, dan memiliki corak bisnis yang berbeda dengan sharing economy di negara-negara kapitalis;

3. Untuk mengetahui sejauh mana pelanggan di Jakarta semakin mengandalkan Go-Jek sebagai moda transportasi yang efisien, menggeser moda transportasi konvensional;

4. Untuk mengetahui mengetahui sejauh mana kesiapan regulasi dalam menghadapi tantangan kemunculan disruptor seperti Go-Jek.

\section{BAHAN DAN METODE}

Untuk mendukung penelitian ini, penulis telah menyertakan beberapa teori pendukung, diantaranya:

\subsection{Inovasi Disruptif}

Inovasi disruptif (disruptive innovation), menjelaskan proses dimana produk/jasa yang awalnya sepele dan tidak dihiraukan berubah dan bertumbuh pesat menjadi pemain utama yang mampu bersaing dengan kompetitor-kompetitor incumbent (Christensen, C., 2013).

Inovasi disruptif bisa dikatakan sebagai proses natural selection bagi bisnis di era berbasis teknologi sekarang ini: berinovasi atau mati. Sesuatu yang menarik dari paham inovasi disruptif ini adalah fakta yang mengatakan bahwa perusahaan-perusahaan besar konvensional tidak lagi menjadi "superhero" dalam hal job creation. Perusahaan-perusahaan rintis/startup, terutama yang berbasis teknologi, pun mampu menciptakan lapangan kerja, serta menciptakan kesempatan pemasukan yang demokratis.

\subsection{Transportasi Umum Informal}

Transportasi umum informal adalah moda transportasi yang dapat ditemui hampir di seluruh benua di dunia. Jenis transportasi ini juga amat popular di Asia, termasuk di Indonesia. Di Jakarta, ada berbagai jenis transportasi umum informal seperti bemo, bajaj, ojek sepeda, dan ojek motor. Tidak banyak yang mengetahui kapan dan bagaimana tepatnya ojek motor bermula.

Menurut majalah Historia (2016), ojek merupakan fenomena yang telah berlangsung beberapa dekade lamanya. Sejak awal, baik ojek sepeda maupun ojek motor tidak pernah memiliki izin resmi dari pemerintah. Meski tahun 1979. Hingga saat ini, penelitian tentang ojek amat jarang dan seringkali terfokus dengan kasuskasus dalam skala kecil di luar kota Jakarta.

\subsection{Transportasi Online}

Transportasi online merupakan transportasi yang berbasis suatu aplikasi tertentu, dimana konsumen memesan suatu sarana transportasi melalui sistem aplikasi di dalam smartphone. Transportasi online memiliki beberapa kelebihan dan kelemahan dibandingkan transportasi umum informal. Adapun kelebihan transportasi Online (Hendrayanti,2018) :

1. Lebih mudah dan praktis tidak perlu menghampiri pangkalan ojek ataupun menunggu di pinggir jalan untuk mendapatkan angkutan umum konvensional

2. Selain itu, para penumpang juga tidak terlibat dalam proses tawar-menawar karena tarif yang sudah ditentukan berdasarkan jarak tempuh.

3. Pergerakan kendaraan yang ditumpanginya termonitor oleh kantor pusat.

Sedangkan kelemahan dari Transportasi Online (Hendrayanti, 2018) :

1. Kesalahan dalam jaringan sehingga membuat penumpang kesulitan

2. Data penumpang mudah tersebar

3. Tidak dapat berpindah lokasi tujuan

4. Tidak bisa memilih ojek yang akan dinaiki

\subsection{Kualitas Pelayanan}

Kualitas pelayanan (service quality) dapat diketahui dengan cara membandingkan persepsi para konsumen atas pelayanan yang nyata-nyata mereka terima/peroleh dengan pelayanan yang sesungguhnya mereka harapkan/inginkan terhadap atribut-atribut pelayanan suatu perusahaan. Jika jasa yang diterima atau dirasakan (perceived service) sesuai dengan yang diharapkan, maka kualitas pelayanan dipersepsikan baik dan memuaskan, jika jasa yang diterima melampaui harapan konsumen, maka kualitas pelayanan dipersepsikan sangat baik dan berkualitas. Sebaliknya jika jasa yang diterima lebih rendah daripada yang diharapkan, maka kualitas pelayanan dipersepsikan buruk.

Kualitas pelayanan memiliki beberapa dimensi atau unsur kualitas pelayanan. Unsur-unsur kualitas pelayanan merupakan hasil temuan penelitian dari teori kualitas pelayanan (A. Pasuraman, 2014). Sebagai salah satu tokoh pionir dalam pengukuran kualitas pelayanan, Pasuraman mencetuskan dimensi servqual. Dimensi ini 
dibuat untuk mengukur kualitas pelayanan dengan menggunakan suatu kuesioner. Teknik servqual dapat mengetahui seberapa besar jarak harapan pelanggan dengan ekspektasi pelanggan terhadap pelayanan yang diterima. Servqual memiliki 5 dimensi, yaitu:

1. Reliability (Kehandalan)

Reliability adalah kemampuan perusahaan untuk memberikan pelayanan yang sesuai dengan harapan konsumen terkait kecepatan, ketepatan waktu, tidak ada kesalahan, sikap simpatik, dan lain sebagainya.

2. Responsiveness (Daya tanggap)

Responsiveness adalah tanggap memberikan pelayanan yang cepat atau responsif serta diiringi dengan cara penyampaian yang jelas dan mudah dimengerti.

3. Assurance (Jaminan)

Assurance adalah jaminan dan kepastian yang diperoleh dari sikap sopan santun karyawan, komunikasi yang baik, dan pengetahuan yang dimiliki, sehingga mampu menumbuhkan rasa percaya pelanggan.

4. Emphaty

Empathy adalah memberikan perhatian yang tulus dan bersifat pribadi kepada pelanggan, hal ini dilakukan untuk mengetahui keinginan konsumen secara akurat dan spesifik.

5. Tangible

Tangibles adalah bukti konkret kemampuan suatu perusahaan untuk menampilkan yang terbaik bagi pelanggan. Baik dari sisi fisik tampilan bangunan, fasilitas, perlengkapan teknologi pendukung, hingga penampilan karyawan.

\subsection{Metode Penelitian}

Penelitian ini menggunakan tipe penelitian deskriptif dengan pendekatan kualitatif. Dalam penelitian yang menggunakan tipe penelitian deskriptif bertujuan untuk mendapatkan gambaran umum tentang tindakan sosial yang dilakukan pengguna Go-Jek dalam pemilihan transportasi. Dengan menggunakan pendekatan kualitatif juga bertujuan untuk memahami makna yang terdapat dibalik setiap tindakan manusia sebagai hasil melakukan interaksi dengan masyarakat lainnya. Penelitian menggunakan pendekatan kualitatif juga dapat mendapatkan jawaban yang lebih mendalam tentang individu sebagai pengguna Go-Jek dalam memberikan jawaban tindakan sosial yang dilakukan dalam pemilihan transportasi yang dilihat melalui perspektif teori tindakan sosial Max Weber.

Informan merupakan elemen penting dalam sebuah penelitian karena informan merupakan sumber utama dalam mendapatkan data yang akurat dan dapat memberikan informasi dan menjawab permasalahan yang diangkat dalam penelitian ini. Di dalam penelitian ini, pemilihan informan dilakukan dengan menggunakan metode purposive, di mana informan yang terpilih sesuai dengan kriteria yang telah ditentukan sebelumnya.
Adapun kriteria informan yang telah ditentukan sebagai berikut: Individu yang pernah, kadang, dan sering menggunakan Go-Jek sebagai pemilihan moda transportasi. Usia dalam penelitian bervariasi, mulai dari pengguna yang masih dalam usia produktif seperti pelajar, mahasiswa, karyawan hingga pengguna yang sudah tidak dalam usia produktif seperti lansia. Variasi latar belakang kondisi sosial dan ekonomi pengguna juga menjadi kriteria dalam penelitian ini.

Untuk mendapatkan jawaban yang mendalam, akurat, dan dapat dipertanggung jawabkan dari informan penelitian, peneliti melakukan pengumpulan data dengan menggunakan wawancara mendalam. Wawancara mendalam (in-depth interview) adalah teknik pengumpulan data dengan cara melakukan percakapan secara intensif dengan informan penelitian. Wawancara ini dilakukan secara terbuka dengan menggunakan pedoman wawancara yang telah dibuat sebelumnya. Hasil dari wawancara mendalam tersebut akan menjadi data primer dalam penelitian ini.

Selain wawancara mendalam, peneliti juga melakukan observasi lapangan untuk mendapatkan datadata pendukung. Observasi lapangan dilakukan peneliti pada saat sebelum merancang proposal penelitian ini. Peneliti melakukan observasi dengan cara selalu memperhatikan setiap pengguna yang sedang memesan dan menggunakan Go-Jek di lokasi tertentu, selain itu observasi juga dilakukan peneliti dengan cara peneliti juga menggunakan Go-Jek, dengan begitu peneliti dapat mengetahui juga pengalaman-pengalaman yang dialami pengguna Go-Jek lainnya dalam menggunakan Go-Jek.

Selain wawancara mendalam dan observasi, dalam pengumpulan data peneliti juga menggunakan jurnal ilmiah dan buku untuk mendukung temuan penelitian. Jurnal dan buku digunakan sebagai data pendukung dalam perancangan penelitian dan proses analisis data. Jurnal ilmiah dan buku dapat dijadikan panduan sehingga dalam proses merancang hasil penelitian mendapatkan hasil yang akurat.

Setelah semua data terkumpul, akan dilakukan analisis data dengan mengelompokkan data dari hasil wawancara mendalam. Pengelompokan disesuaikan dengan item pertanyaan yang telah dibuat untuk menjawab rumusan masalah dalam penelitian ini. (Sugiyono 2017)

Langkah - langkah dalam analisis data, antara lain:

1. Mengolah dan mempersiapkan data untuk dianalisis.

2. Membaca keseluruhan data.

3. Menganalisis lebih detail dengan meng-coding data.

4. Menerapkan proses coding untuk mendeskripsikan setting, subjek, kategori dan tema yang akan dianalisis.

5. Menyajikan kembali deskripsi dan tema dalam narasi atau laporan secara kualitatif dengan menerapkan pendekatan naratif dalam menyampaikan hasil analisis yang meliputi kronologi peristiwa, tema tertentu, atau keterhubungan antar tema. Setelah data 
terkumpul dan telah dikategorisasikan, data kemudian akan ditampilkan dalam bentuk kutipan dengan narasi agar lebih mudah dipahami.

6. Interpretasi atau pemaknaan data. Interpretasi dalam penelitian kualitatif dapat berupa banyak hal yang dapat diadaptasi untuk jenis rancangan yang berbeda dan dapat bersifat pribadi, berbasis penelitian maupun tindakan. Dalam hal ini, ketika temuan data telah selesai dijabarkan dalam bentuk kutipan dan telah dijelaskan, hasil temuan data tersebut kemudian dapat di interpretasi dan dimaknai dengan dasar teori yang sesuai dengan fokus penelitian yang telah ditentukan

\section{PEMBAHASAN}

PT. Go-Jek Indonesia Go-Jek adalah perusahaan teknologi berbasis aplikasi telepon genggam yang bertujuan untuk memperbaiki harkat hidup para pekerja sektor informal di Indonesia. Berbeda dengan pelayanan jasa ojek, perusahaan ini melayani berbagai kebutuhan yang diperlukan masyarakat di daerah-daerah padat penduduk seperti megalopolis Jabodetabek, Bandung, Surabaya, Medan, Yogyakarta, Makassar, Denpasar, Semarang, Balikpapan, Palembang.

Perusahaan ini melakukan inovasi yang tak henti, baik dalam hal layanan maupun sarana utama pendukung usaha, yaitu aplikasi. Saat ini Go-Jek memiliki kurang lebih 200.000 mitra di Indonesia, separuhnya berada di JABODETABEK. Pengemudi Go-Jek yang sering kita lihat tidak berstatus karyawan, namun mitra. Aplikasi Go-Jek merupakan salah satu aplikasi lokal yang paling banyak diunduh. PT. Go-Jek menargetkan 10 juta unduhan aplikasi di tahun 2016.

Go-Jek dapat dikategorikan sebagai inovasi disruptif. Inovasi Disruptif (disruptive innovation), pada esensinya adalah perubahan, sebuah gangguan bagi yang pemain pasar yang telah lama mapan dan memaksa mereka untuk mempertimbangkan opsi mereka dalam membendung sepak terjang pemain baru. Inovasi Disruptif merupakan istilah yang diperkenalkan oleh seorang professor dari Universitas Harvard, Clayton Christensen. Dijelaskan, bahwa dalam sebuah industri, pemain utama cenderung mencurahkan energi mereka pada inovasi berkesinambungan, yakni menambahkan fitur-fitur baru pada produk mereka yang telah lama menguasai pasar. Inovasi-inovasi yang mereka letakkan pada produk jawara mereka, bertujuan agar pelanggan membayar lebih mahal untuk barang/jasa tersebut. Namun risiko yang sering dipandang sebelah mata oleh para pemain ini adalah kenyataannya, pelanggan seringkali menginginkan solusi yang tepat guna sekaligus terjangkau oleh kantong mereka. Pada saat itulah, kompetitor baru mulai bermunculan. Mereka menawarkan hal-hal sederhana yang dibutuhkan pelanggan dan sesuai dengan bujet yang pelanggan inginkan. Dari contoh ini dapat kita bercermin dengan contoh yang kini ramai diperdebatkan di Indonesia yaitu aplikasi moda transportasi Go-Jek dengan incumbent transportasi urban, Taksi Bluebird. Meski berbeda alat transportasi yang digunakan kedua perusahaan tersebut. Inovasi disruptif, sering kali tidak memiliki platform dialog dan sering disepelekan. Namun, ketika kehadiran mereka mulai dirasakan secara signifikan, maka sering kali hal-hal buruk mulai timbul, menjadi sorotan masyarakat, bahkan menuai resistensi kompetitor. Contohnya demonstrasi penolakan aplikasi moda transportasi oleh Paguyuban Pengemudi Angkutan Darat (PPAD) yang terjadi di Jakarta tanggal 22 Maret 2016.

Jika sebelumnya telah terjadi resistensi Ojek konvensional terhadap Go-Jek, secara sporadis di berbagai tempat di Jakarta dan kota-kota lain, demonstrasi PPAD tanggal 22 Maret 2016 menuntut penutupan masif aplikasi moda transportasi UBER dan GRAB. PPAD menganggap bahwa aplikasi moda transportasi mengancam pemasukan mereka dan perusahaan tempat mereka bekerja.

Mogok massal penyedia jasa angkutan urban akibat kehadiran bisnis-bisnis disruptif, bukanlah hal yang baru lagi. Sebelum Jakarta, tentangan terhadap disruptor telah terjadi di berbagai negara termasuk Amerika Serikat, dimana konsep inovasi disruptif pertama kali diperkenalkan. Hal ini terjadi karena pada umumnya regulator (pemerintah) tidak begitu memperhatikan potensi dan dampak yang mungkin terjadi berkat (atau akibat) bisnis-bisnis disruptor. Di sisi lain, para disruptor tidak mau dan tidak mampu menunggu para regulator untuk membakukan aturan untuk jenis-jenis bisnis baru terutama setelah menimbang bahwa transportasi bagi masyarakat urban seperti Jakarta dan kota-kota besar Indonesia lainnya merupakan kebutuhan penting dan mendesak, dan tidak bisa ditangani sepenuhnya oleh perusahaan-perusahaan incumbent

Penelitian ini mengandalkan pengumpulan data berbentuk wawancara. Terdapat dua macam wawancara, yaitu observational survey dengan metode electronic survey (e-survei), dan wawancara mendalam (Sugiyono: 2017). E-survei dibuat menggunakan platform Google Forms, dan disebar via e-mail kepada pelanggan Go-Jek di Jakarta.

Hasil wawancara survei pelanggan adalah sebagai berikut:

1. Sebagian besar pelanggan Go-Jek adalah karyawan swasta

2. Berusia antara 18-40 tahun, dan mayoritas mencoba Go-Jek atas rekomendasi teman/kerabat.

3. Sebagian besar rutin menggunakan satu atau lebih layanan Go-Jek, selama kurang-lebih 6 (enam) bulan.

4. Ketika ditanya alasan mereka memilih Go-Jek, jawaban umum pertama adalah "efisiensi waktu" (21\% dari total jawaban), diikuti dengan "tarif murah" (20\% dari total jawaban). Alasan favorit lain yang disebut responden, antara lain: coba-coba ("rasa penasaran", $14 \%$ dari total jawaban), dan app 
convenience and usefulness ("efisiensi aplikasi" (11\% dari total jawaban).

5. Layanan terpopuler Go-Jek menurut informan wawancara survei adalah Go-Ride $(51 \%$ dari total jawaban), disusul dengan Go-Food (30\% dari total jawaban), Go-Send (13\% dari total jawaban), dan Go-Mart (5\%). Beberapa layanan Go-Jek masih belum popular karena baru diperkenalkan ke dalam pasar.

E-survei kedua ditujukan kepada para mitra Go-Jek, dimana hasil wawancara survei Mitra Go-Jek adalah sebagai berikut:

1. Sebagian besar mitra Go-Jek adalah lulusan SMA/sederajat dan $50 \%$ dari informan survei memiliki tanggungan.

2. Sebagian besar dari mereka memiliki pengalaman kerja, baik dalam perusahaan lain maupun berwiraswasta

3. Sebagian dari mereka (64\% dari jumlah informan) mengakui kisaran pemasukan bulanan mereka adalah 2-4 juta Rupiah. Sebagai perbandingan, Upah Minimum Provinsi DKI Jakarta yang disetujui untuk tahun 2016 adalah 3,1 juta Rupiah, meningkat dari 2,7 juta Rupiah di tahun 2015. Ketika ditanya hal-hal menarik apa yang ditawarkan Go-Jek, jawaban dominan adalah "kesempatan bekerja" (19\% dari total jawaban), disusul dengan jawaban "kebebasan menentukan waktu kerja", "pemasukan tambahan", dan "keahlian baru" (masing-masing 14\% dari total jawaban).

Selain menyebar e-survei, peneliti melakukan wawancara mendalam terhadap 6 (enam) orang informan, yang adalah pelanggan Go-Jek di Jakarta.

Untuk menggali pendapat informan dan mengekspos fenomena inovasi disruptif, peneliti menggunakan pokok-pokok pertanyaan Apa, Dimana, Kapan, Siapa, Mengapa, dan Bagaimana (ADIK SIMBA) atau yang dikenal sebagai rumus $5 \mathrm{~W}+1 \mathrm{H}$ yang biasa digunakan dalam teknik penggalian ide penulisan. Wawancara menggunakan gaya bahasa wawancara informal, disampaikan dalam bahasa Indonesia dan Inggris. Seluruh hasil wawancara dalam bahasa Inggris yang diikuti sertakan dalam bab ini telah diterjemahkan.

Semua informan wawancara mendalam adalah mereka yang berdomisili di Jakarta, baik Warga Negara Indonesia (WNI) maupun Warga Negara Asing (WNA) yang pernah menggunakan aplikasi Go-Jek.

Adapun hasil wawancara dengan 6 (enam) Informan dapat dijelaskan sebagai berikut:

1. Menurut Informan I, fenomena Go-Jek adalah fenomena pembangunan yang tidak terelakkan (inevitable), namun amat disayangkan pemerintah Indonesia lambat mengantisipasi resistensi yang telah terjadi di negara-negara lain. menurut Informan I, kenyamanan merupakan faktor utama Informan I memilih Go-Jek di hampir satu tahun terakhir. Hasil wawancara mendalam dapat dilihat sebagai berikut:
Informan I masih menggunakan moda transportasi konvensional lain, namun untuk beberapa hal menurut Informan I, Go-Jek menawarkan kenyamanan yang dicari pelanggan seperti dirinya.

2. Bagi Informan II Go-Jek sebagai moda transportasi memiliki sisi negatif dan positif. Dari sudut pandang positif, Go-Jek mempercepat penggunanya berangkat dari titik A menuju titik $\mathrm{B}$, namun moda transportasi seperti halnya Go-Jek masih memiliki banyak kekurangan salah satunya ketidaktertiban mitra menggunakan trotoar yang adalah fasilitas kota sebagai lahan parkir, sehingga berkontribusi menimbulkan kemacetan baru. Dia beranggapan bahwa adalah wajar apabila penyedia jasa transportasi konvensional protes terhadap kehadiran inovasi transportasi, namun ada kesalahpahaman dari pihak demonstran tentang apa yang seharusnya dibenahi. Perusahaan-perusahaan transportasi incumbent telah lama dimanjakan oleh peraturan, sehingga mereka menutup mata terhadap ketidakadilan yang dialami pelanggan akibat sopirsopir taksi yang berperilaku tidak profesional.

3. Informan III, yang adalah pengusaha kuliner Indonesia, Go-Jek sebagai disruptor memiliki poinpoin istimewa, bahkan jenius, jika dilihat dari sudut pandang pengusaha. Lebih lanjut lagi, Go-Jek sebagai disruptor memiliki potensi yang besar untuk terus berinovasi. Saat ini, menurutnya, Go-Jek telah mempermudah mobilitas para pelanggannya, dan ragam layanan yang mereka tawarkan pun amat menarik. Menanggapi perihal regulasi, Informan III berpendapat bahwa pemerintah tidak sampai menutup paksa Go-Jek.

4. Informan IV mengaku bahwa dirinya bukanlah orang yang akrab dengan teknologi baru, dan pada awalnya menggunakan ojek konvensional sebelum mulai menggunakan Go-Jek. Informan IV mengaku sudah terbiasa dengan prosedur tawar menawar di jalan sebelum dengan ojek konvensional. Hambatan ojek konvensional terjadi saat pengemudi ojek yang bukan langganan seringkali mencoba "memerasnya" dengan cara mematok harga yang tidak wajar. Alasan utamanya menggunakan Go-Jek adalah faktor efisiensi waktu, sedangkan faktor tarif Go-Jek dianggapnya sebagai faktor sekunder.

5. Informan $\mathrm{V}$ mengatakan bahwa sejauh ini dirinya lebih banyak diuntungkan dengan fenomena Go-Jek. Menurutnya, Go-Jek menjadi alat pembelajaran bagi para Orang, terutama dalam hal berinteraksi dengan penumpang dan calon penumpang. Para mitra Go-Jek memiliki hubungan pertemanan yang erat dan solidaritas yang tinggi. Menurut Informan V, saling menolong diantara mereka, sudah menjadi peraturan tidak tertulis yang dihormati oleh seluruh mitra GoJek.

6. Informan VI beranggapan bahwa dalam menyikapi disruptive innovation, tantangan sebenarnya adalah 
memahami makna perubahan yang sebenarnya. Indonesia, menurutnya masih belum sepenuhnya siap. Inovasi disruptif seperti Go-Jek bisa menjadi alternatif, tetapi bukan solusi. Bagi Informan VI, salah satu inovasi dari Go-Jek adalah pemberdayaan pengemudi. Lebih lanjut lagi, Informan VI menggaris bawahi pentingnya bagi pemerintah untuk memberikan ruang untuk pertarungan kompetisi yang adil.

Berdasarkan hasil wawancara di atas, mitra Go-Jek merupakan suatu fenomena inovasi disruptif yang positif dan dianggap sebagai alternatif yang telah lama mereka cari, yaitu transportasi aman, nyaman, cepat dan tepat. Selain itu juga diharapkan peran serta pemerintah

\section{KESIMPULAN}

Dari hasil penelitian yang sudah dijabarkan sebelumnya, dapat ditarik kesimpulan bahwa secara umum, persepsi masyarakat terhadap fenomena Go-Jek terlihat positif. Hal ini terlihat dari respons para pelanggan, yang menganggap bahwa Go-Jek adalah alternatif yang telah lama dicari, ketika transportasi umum semakin menjadi problema pelik di Jakarta. Para pelanggan menganggap bahwa solusi Go-Jek menghadirkan solusi efisien dengan menggunakan moda transportasi yang familiar di masyarakat. Kemampuan Go-Jek dalam membidik problema masyarakat yang tepat menjadikan perusahaan disruptor. Go-Jek telah membuka peluang bekerja bagi mereka yang menginginkan keleluasaan dalam menentukan waktu kerja.

Pelanggan Jakarta mulai menyadari adanya aplikasi moda transportasi Go-Jek, namun tidak sontak aplikasi ini menggantikan moda transportasi umum konvensional.

Berkat Internet, inovasi disruptif kini terjadi di berbagai penjuru dunia, termasuk di Indonesia. Fenomena inovasi disruptif perlu disikapi dengan bijak oleh semua pihak yang terlibat, termasuk masyarakat, pemerintah dan perusahaan-perusahaan incumbent beserta elemen-elemennya. Internet telah menurunkan secara signifikan barrier of entry bagi perusahaanperusahaan rintisan yang kemudian disebut sebagai disruptor bagi perusahaan-perusahaan incumbent.

\section{SARAN}

Go-Jek merupakan fenomena, namun persepsi masyarakat masih cenderung positif atasnya, oleh sebab itu fenomena ini sebaiknya jangan diperlakukan sebagai fenomena negatif. Sebagai perusahaan yang mengutamakan prinsip-prinsip social entrepreneurship, akan sulit sekali bagi Go-Jek untuk memiliki bidang usaha yang berbasis kapitalisme seperti UBER dan AirBnB. Bagaimanapun juga, Go-Jek merupakan perusahaan baru yang membutuhkan framework hukum yang mendukungnya berkembang dan namun membatasinya untuk mempraktikkan kompetisi yang tidak sehat dengan perusahaan-perusahaan incumbent.
Go-Jek memiliki social impact yang mulai dirasakan sedikit demi sedikit, namun Go-Jek perlu menerapkan pola komunikasi inklusif untuk meningkatkan semangat mitra-mitranya sekaligus memperlakukan aspirasi mereka sebagai bagian yang tidak integral dari tiap tahapan inovasi Go-Jek.

Diversifikasi Go-Jek memang menarik namun baik adanya bila tiap inovasi yang luncurkan, melalui proses audit dan Quality Assurance berkala, alih-alih melakukan penanganan insidental.

Sangat mungkin bila Go-Jek akan menjadi salah satu perusahaan transportasi yang berpotensi melakukan IPO di bursa saham, untuk menyikapi kemungkinan ini, penting bagi pemerintah untuk memberikan kepastian hukum bagi moda transportasi ini.

Salah satu kelemahan Sharing economy adalah online reputation management. Artinya, mitra Go-Jek yang memiliki rating tinggi tidak bisa membawa reputasinya ke perusahaan lain apabila dia memutuskan untuk berhenti bermitra dengan Go-Jek. Tidak aneh apabila sharing economy sering dianggap sebagai bibit praktik monopoli baru. Baik adanya apabila Go-Jek mampu berinovasi dan menjadi pionir sharing economy dimana online reputation adalah sepenuhnya milik individu masing-masing.

Dalam menetapkan regulasi, penting bagi pemerintah untuk mengingat sebagian ide-ide usaha disruptor belum ada di era pemerintahan yang lalu. Jika mereka mulai bermunculan di era pemerintahan saat ini, ada baiknya jika pemerintah terus menerus melakukan dialog dengan mereka, alih-alih memaksakan peraturan-peraturan yang dipetik dari pengalaman perusahaan-perusahaan konvensional yang tidak bergantung dengan Internet dan teknologi.

\section{DAFTAR PUSTAKA}

Bayudin. 2019. Inovasi Disruptif di Industri Perhotelan. Retrieved March 26, 2021 from http://journal.undiknas.ac.id/index.php/magistermanajemen/

Christensen, C. 2013. The innovator's dilemma: when new technologies cause great firms to fail. Harvard Business Review Press.

Cosseboom, L. 2015. Tech in Asia - Connecting Asia's startup ecosystem. Retrieved March, 2021, from https://www.techinasia.com/southeast-asiamillennials-technology-adoption

Darma, G.S. 2019. Kacamata Media, Kesuksesan Bersyarat. Indonesia: Pustaka Larasan Press.

Darma, G.S., Apollo, A., Rusmanda, G., and Umar, Y. 2019. Digital Education 4.0. Indonesia: Cakra Media Utama Press.

Darma, G.S. 2018. Seuntai Pesan, Menjawab Zaman. Indonesia: Pustaka Larasan Press.

Dewi, M.V.K., and Darma, G.S. 2019. The Role of Marketing \& Competitive Intelligence In 
Industrial Revolution 4.0, Jurnal Manajemen \& Bisnis, 16 (1): 1-12

Ferdiana, A.M.K., and Darma, G.S. 2019. Understanding Fintech Through Go-Pay, International Journal of Innovative Science and Research Technology, 4 (2): 257-260

Goodman, J. A. 2014. Customer Experience 3.0: Highprofit Strategies in the Age of Techno Service. AMACOM Div American Mgmt Assn.

Hanggoro, H. T. 2015. Mengorek Sejarah Ojek | Historia. Retrieved March, 2021, from http://historia.id/kota/mengorek-sejarah-ojek

Hendrayanti, Alberta, J.A., 2018. Pengaruh Angkutan Umum di Daerah Istimewa Yogyakarta Fakultas Teknik Universitas Atma Jaya Yogyakarta.

J. K. 2012. Tech in Asia - Connecting Asia's startup ecosystem. Retrieved March 28, 2021, from https://www.techinasia.com/Go-Jek-indonesia

Kasali, Rhenald. 2017. Manajemen Public Relations. Jakarta: PT Pustaka UtamaGrafiti

Kemenkominfo. 2016. Indonesia Raksasa Teknologi Digital Asia. Retrieved March, 2021, from https://kominfo.go.id/index.php/content/detail/6 095/Indonesia Raksasa Teknologi Digital Asia/0/sorotan_media
Kostakis, V., \& Bauwens, M. 2014. Network society and future scenarios for a collaborative economy. Palgrave Macmillan.

Schor, J. 2016 The sharing economy: Hyper-capitalism or a sustainable alternative? Retrieved March 28, 2021, from https://www.youtube.com/watch?v=Qq7GyF3smc

Setyanti, E. P. (n.d.). 2015. Tech in Asia Indonesia Komunitas Online Startup di Asia. Retrieved March, 2021, from https://id.techinasia.com/survei-googleindonesia-penetrasi-smartphone-dalam-negeri

Sugiyono. 2017, Statistika Untuk Penelitian, Bandung: CV. ALFABETA.

Widia Darma, Inovasi Diskruptif (Disruptive Innovation) Dalam Pendidikan, 2018 from https://osf.io/pqk79/download/?format=pdf

\section{UCAPAN TERIMA KASIH}

Terima kasih kepada keluarga besar STIE UniSadhuguna yang telah mendukung penelitian ini sampai diterbitkannya jurnal penelitian ini. Tak lupa kami ucapkan banyak terima kasih kepada keluarga kami masing-masing atas support baik secara materi dan non materi hingga penelitian ini dapat terwujud. 